\title{
PENGGUNAAN SKIMMING METHOD DALAM MEMAHAMI JURNAL BERBAHASA INGGRIS PADA MAHASISWA DI STIE AUB SURAKARTA
}

\author{
Hanif Safika Rizky', Yenni Khristiana ${ }^{2}$ \\ Program Studi Akuntansi STIE Adi Unggul Birawa Surakarta \\ Korespondensi: Jalan Mr. Sartono No.46, Surakarta, Jawa Tengah \\ Surel: hanifsafika@stie-aub.ac.id
}

INFO ARTIKEL

Sejarah Artikel:

Diterima: 27/06/2020

Direvisi: 03/09/2020

Dipublikasikan: 30/09/2020

e-ISSN: 2721-0995

p-ISSN: 2721-9046

Kata Kunci:

Skimming method, pemahaman, jurnal, bahasa Inggris

Keywords:

Skimming method, understanding, journal, English
ABSTRAK

Penggunaan Skimming Method dalam Memahami Jurnal Berbahasa Inggris pada Mahasiswa di STIE AUB Surakarta. Penggunaan skimming method untuk membaca jurnal berbahasa Inggris dapat meningkatkan penguasaan Bahasa Inggris dan dapat meningkatkan kemampuan pemahaman isi teks berbahasa Inggris oleh mahasiswa di STIE AUB Surakarta. Peneliti menggunakan metode penelitian kualitatif. Dalam penelitian ini, mahasiswa STIE AUB Surakarta sebagai subjek penelitian. Hasil penelitian ini menunjukkan bahwa hasil tes sebelum mendapat pemahaman tentang penggunaan skimming method dalam membaca jurnal dan hasil tes sesudah mendapat pemahaman berbeda dan menunjukkan kenaikan kemampuan Bahasa Inggris mahasiswa, pada teknik uji $\mathrm{T}$ pada tes sebelum dan sesudah dengan hasil 6,6 > 1,72 atau signifikan. Dengan demikian dapat disimpulkan bahwa penggunaan skimming method dalam membaca jurnal berbahasa Inggris oleh mahasiswa di STIE AUB Surakarta dapat meningkatkan penguasaan Bahasa Inggris dan pemahaman isi teks berbahasa Inggris.

\footnotetext{
ABSTRACT Using of Skimming Method in Understanding English Journal by Students at STIE AUB Surakarta. The use of skimming method to read English journals can improve the mastery of English and can improve the ability to understand the contents of English texts by students at STIE AUB Surakarta. Researchers used qualitative research methods. Where is this research, STIE AUB Surakarta students as research subjects. The results of this study indicate that the test results before gaining an understanding of the use of skimming methods in reading journals and test results after gaining a different understanding and showing an increase in students' English proficiency, in the $T$ test technique on tests before and after where with results 6.6> 1, 72 or significant. So it can be concluded that the use of skimming method in reading English journals by students at STIE AUB Surakarta can improve the mastery of English and understanding the contents of English texts.
} 


\section{PENDAHULUAN}

Pada masa sekarang ini dalam mempelajari hal-hal baru, mahasiswa sering menemukan bahasa Inggris sebagai bahasa pengantar. Namun, hal ini menjadi masalah baru bagi mahasiswa karena tidak menggunakan Bahasa Inggris secara aktif baik dalam berbicara maupun menulis. Padahal sebagian besar negara-negara di Benua Asia, Afrika, Amerika, Eropa, dan Australia menggunakan Bahasa Inggris sebagai bahasa pergaulan internasional untuk memudahkan mereka dalam berinteraksi. Karena itulah penggunaan Bahasa Inggris digunakan juga dalam bidang ekonomi, sosial, keilmuan dan sebagainya untuk memudahkan orang-orang yang berbeda negara dan budaya untuk saling memahami. Menurut Sudrajat (2015), Bahasa Inggris adalah bahasa asing yang dianggap penting untuk tujuan ilmu pengetahuan, teknologi, dan seni budaya, serta pengembangan hubungan antara negara-negara di bumi ini.

Penggunaan metode dalam proses belajar dan mengajar Bahasa Inggris diperlukan dalam mendukung keberhasilan mahasiswa agar memiliki kemampuan Bahasa Inggris yang lebih baik. Penggunaan metode yang mudah dipahami dan dilakukan akan membuat mahasiswa dapat menerima pembelajaran dengan baik. Mahasiswa telah mengenal Bahasa Inggris ketika mereka masuk bangku sekolah mulai dari tingkat Sekolah Dasar hingga Sekolah Menengah Atas atau Sekolah Menengah Kejuruan. Oleh karena itu, mereka mestinya tidak asing dengan Bahasa Inggris baik tata bahasa maupun kosakata.

Dalam kemampuan berbahasa Inggris, selain terampil berbicara, mahasiswa perlu mempunyai keterampilan membaca, memahami isi, dan menyimak yang merupakan keterampilan berbahasa. Mahasiswa selalu diarahkan untuk meningkatkan kemampuannya dalam berbahasa Inggris agar dapat berguna bagi mahasiswa itu sendiri dalam memahami segala sesuatu yang menggunakan Bahasa Inggris sebagai bahasa komunikasi internasional. Berdasarkan uraian di atas, penggunaan metode dalam proses belajar dan mengajar berpengaruh dalam meningkatkan kemampuan Bahasa Inggris, termasuk kemampuan pemahaman isi teks berbahasa Inggris. Oleh karena itu, peneliti tertarik untuk mengetahui apakah dalam penggunaan metode membaca skimming method dalam proses belajar dan mengajar dapat meningkatkan kemampuan pemahaman isi teks, khususnya jurnal berbahasa Inggris bagi mahasiswa.

\section{TINJAUAN PUSTAKA}

Kemampuan berbahasa menurut Soenardi (2011) dibagi menjadi empat jenis kemampuan, di antaranya adalah kemampuan menyimak, kemampuan membaca, kemampuan berbicara, dan kemampuan menulis. Berdasarkan penjelasan tersebut maka dapat disimpulkan bahwa kemampuan berbahasa seseorang dapat dilihat melalui kesanggupan seseorang tersebut dalam menjelaskan simbol melalui aktivitas berbahasa yang menunjukkan wawasan dan kecakapannya. Jadi, dalam mengembangkan kecakapan berbahasa, perlu adanya kemahiran untuk menyimak dan membaca sehingga kemahiran dalam berbicara dan menulis bahasa asing akan meningkat.

Selanjutnya, Supriatnoko dan Redyanita (2017) menjelaskan pemakaian magic five fingers method mampu meningkatkan kemampuan mahasiswa dalam membuat kalimat- 
kalimat pertanyaan dan jawaban serta mampu meningkatkan kemahiran berbicara dalam Bahasa Inggris. Lalu ada Fitria \& Heliawan (2017) yang menjelaskan bahwa membaca dengan metode scanning adalah metode yang dapat membimbing pelajar dalam meningkatkan kemampuan membaca, khususnya mencari informasi. Kedua persamaan penelitian tersebut ialah pemanfaatan metode pembelajaran dalam mengajar Bahasa Inggris untuk meningkatkan kemampuan para mahasiswa.

Menurut Suryoputro, Riadi, \& Sya'ban (2012), jurnal ilmiah adalah sebuah publikasi yang diterbitkan secara berkala oleh suatu organisasi profesi atau institusi akademik yang memuat artikel-artikel yang merupakan produk pemikiran ilmiah secara nyata berupa artikel dari hasil penelitian maupun pemikiran di bidang ilmu tertentu. Berdasarkan penjelasan tersebut dapat ditarik kesimpulan bahwa jurnal adalah terbitan secara periodik yang dimuat instansi akademik, atau organisasi profesi, dan lembaga keilmuan yang berisi artikel hasil dari penelitian yang telah dilakukan sebelumnya. Jadi jurnal adalah wewenang pengembangan ipteks yang berada pada institusi akademik atau organisasi profesi untuk menerbitkan produk hasil penelitian secara ilmiah.

Skimming menurut Widiatmoko (Puspita, 2018) adalah suatu perilaku membaca menggunakan kecepatan tinggi dalam mencapai pokok pikiran dari bacaan. Jadi membaca dengan skimming method dapat memperoleh informasi yang penting, khususnya dalam membantu pembaca mendapatkan informasi tertentu dengan tempo waktu yang relatif singkat. Selanjutnya menurut Ahmad (2010), tahapan-tahapan membaca dengan skimming method adalah sebagai berikut:

a. Perhatikan judulnya secara seksama. Apa saja implikasi-implikasinya. Pusatkan pada kata yang penting di dalam judul tersebut.

b. Perhatikan subdivisi, pembagian-pembagian selanjutnya untuk memperoleh apresiasi struktur tulisan.

c. Amati grafik, tabel, gambar, atau foto sehingga memudahkan dalam memperjelas makna atau arti.

d. Lihat paragraf, panjang atau pendeknya, bentuk hurufnya, miring, cetak tebal berfungsi dalam mengetahui dan memisahkan suatu hal yang penting.

Menurut Noverilan (2012), keterampilan membaca pemahaman memberi sumbangan besar terhadap keterampilan menulis siswa. Selaras dengan itu, di dalam penelitian yang dilakukan oleh Mulyadi (2014) juga menyimpulkan bahwa keterampilan membaca pemahaman memberi sumbangan besar terhadap hasil belajar, terutama dalam keterampilan menulis. Berdasarkan penjelasan tersebut dapat ditarik kesimpulan bahwa keterampilan membaca pemahaman dapat membuat seseorang terampil dalam mengungkapkan maksud di dalam bacaan atau teks yang kemudian bisa menunjang atau meningkatkan keterampilan menulis seseorang. 


\section{METODE}

Peneliti menggunakan metode penelitian kualitatif. Maksud dari penelitian kualitatif adalah peneliti yang menggambarkan objek penelitian berdasarkan fakta yang terlihat, sehingga penelitian didukung oleh fakta yang didapat di lapangan. Selanjutnya populasi adalah tempat generalisasi yang terdiri atas objek atau subjek, mempunyai kualitas dan karakteristik tertentu yang ditetapkan oleh peneliti untuk dipelajari dan kemudian ditarik kesimpulan (Sugiyono, 2012). Populasi penelitian ini, yaitu mahasiswa STIE AUB Surakarta tahun 2019. Penelitian ini mengambil sampel mahasiswa di STIE AUB yang menggunakan jurnal berbahasa Inggris dengan menggunakan metode membaca, yaitu skimming method di dalam proses belajar dan mengajar. Alasannya adalah untuk mengetahui bagaimana mahasiswa di STIE AUB Surakarta tahun 2019 dapat memahami isi jurnal berbahasa Inggris dan meningkatnya kemampuan Bahasa Inggris mereka dengan menggunakan skimming method.

Instrumen penelitian menurut fungsinya adalah suatu alat yang digunakan untuk mengumpulkan data dalam sebuah penelitian. Maka dalam penelitian ini harus ada alat yang digunakan secara tepat. Adapun instrumen atau alat yang digunakan untuk penelitian ini yaitu observasi dan tes kepada mahasiswa. Sampel penelitian ini diambil dari mahasiswa di STIE AUB Surakarta yang berjumlah dua puluh sampel mahasiswa. Sampel yang diambil dari hasil tes baik berupa pre-test dan post-test mahasiswa di tahun 2019.

\section{HASIL DAN PEMBAHASAN}

Penelitian ini memiliki tujuan untuk menguji penggunaan jurnal berbahasa Inggris dengan teknik membaca skimming method dalam meningkatkan kemampuan Bahasa Inggris dan pemahaman isi teks berbahasa Inggris pada mahasiswa. Untuk mendapatkan hasil penelitian diperlukan tahapan sebagai berikut, yaitu terbagi tiga tahapan, yaitu:

1. Tahap pertama adalah pretes, pada tahap pretes mahasiswa dites atau diuji langsung secara mendadak tanpa persiapan. Tahapan ini perlu dilakukan agar hasil yang diperoleh berdasarkan kemampuan objektif mahasiswa yang sebenarnya.

2. Tahap kedua adalah proses pembelajaran membaca, yakni mahasiswa diberi penjelasan tentang penerapan metode membaca sekilas (skimming). Kegunaannya adalah mahasiswa mampu dan paham dalam mengimplementasikan skimming method ketika dalam proses membaca.

3. Tahap ketiga adalah postes, tahapan ini sangat penting karena bertujuan untuk mengukur hasil akhir apakah ada peningkatan atau penurunan dalam aktivitas membaca jurnal berbahasa Inggris pada mahasiswa STIE AUB Surakarta.

Tahapan-tahapan tersebut dilakukan dengan tepat sehingga hasil penelitian dapat diperoleh sebagai berikut:

1. Tahapan Pretes 
Sebelum mahasiswa diberikan materi tentang skimming method, mahasiswa terlebih dahulu diuji dengan jurnal berbahasa Inggris yang berjudul sebagai berikut "Financial Development and Economic Growth: A Case of Indian Economy", tahapan ini perlu dilakukan untuk mengetahui kemampuan dasar dari para mahasiswa. Tes dilakukan dengan tertulis, yaitu tes berisi sepuluh pertanyaan dan mahasiswa harus menjawab pertanyaan tersebut berdasarkan bacaan berupa jurnal berbahasa Inggris yang telah diberikan.

Tabel 1.

Nilai Pretes Mahasiswa

\begin{tabular}{|c|l|c|}
\hline $\begin{array}{c}\text { Nomor } \\
\text { Urut }\end{array}$ & Mahasiswa & $\begin{array}{c}\text { Nilai } \\
\text { Pretes }\end{array}$ \\
\hline 1. & Mahasiswa 1 & 5 \\
\hline 2. & Mahasiswa 2 & 5 \\
\hline 3. & Mahasiswa 3 & 6 \\
\hline 4. & Mahasiswa 4 & 7 \\
\hline 5. & Mahasiswa 5 & 6 \\
\hline 6. & Mahasiswa 6 & 7 \\
\hline 7. & Mahasiswa 7 & 4 \\
\hline 8. & Mahasiswa 8 & 5 \\
\hline 9. & Mahasiswa 9 & 6 \\
\hline 10. & Mahasiswa 10 & 6 \\
\hline 11. & Mahasiswa 11 & 7 \\
\hline 12. & Mahasiswa 12 & 7 \\
\hline 13. & Mahasiswa 13 & 5 \\
\hline 14. & Mahasiswa 14 & 5 \\
\hline 15. & Mahasiswa 15 & 5 \\
\hline 16. & Mahasiswa 16 & 6 \\
\hline 17. & Mahasiswa 17 & 7 \\
\hline 18. & Mahasiswa 18 & 4 \\
\hline 19. & Mahasiswa 19 & 5 \\
\hline 20. & Mahasiswa 20 & 6 \\
\hline & & \\
& &
\end{tabular}

2. Tahapan Pembelajaran Membaca dengan Skimming Method

Pada tahapan selanjutnya peneliti melakukan tahapan pembelajaran, yaitu memakai metode membaca dalam pembelajaran Bahasa Inggris yaitu dengan skimming method. Pembelajaran dilaksanakan dengan tahapan-tahapan, sebagai berikut:

a. Tahap Pertama adalah Prapembelajaran

Pada tahap ini peneliti melakukan beberapa keperluan pembelajaran di antaranya membuat RPP, menyediakan alat implementasi tindakan, mempersiapkan bacaan jurnal berbahasa Inggris, dan alat untuk evaluasi. 
b. Tahap Kedua adalah Pembelajaran Membaca yang meliputi:

(1) Mengidentifikasi keperluan mahasiswa

Mencari kemungkinan informasi penting yang diperlukan mahasiswa terdapat dalam bacaan jurnal tersebut.

(2) Menjelaskan permasalahan yang sering dihadapi mahasiswi Di sini dosen atau pengajar memberikan pengalaman dan permasalahan yang sering dijumpai dalam membaca jurnal berbahasa Inggris yang biasa dialami oleh mahasiswa, sehingga mahasiswa termotivasi dan terdorong untuk lebih memahami jurnal berbahasa Inggris dengan metode dan motivasi yang akan diberikan.

(3) Menyediakan kelas yang sesuai dan peralatan yang mendukung.

(4) Karena dalam membaca diperlukan tingkat konsentrasi yang cukup tinggi untuk memperoleh informasi. Maka mahasiswa diberi penjelasan dan pengertian untuk meminimalkan gangguan dan bersikap tenang ketika membaca, khususnya membaca jurnal berbahasa Inggris.

(5) Dosen memberikan penjelasan tentang skimming method kepada mahasiswa dalam membaca jurnal berbahasa Inggris.

\section{Tahapan Postes}

Postes dilakukan setelah mahasiswa mendapatkan pengetahuan dan kemampuan tentang penggunaan skimming method dalam membaca jurnal berbahasa Inggris dari pengajar atau dosen di tahap pembelajaran. Kemudian, dalam postes mahasiswa diuji lagi dengan menggunakan jurnal berbahasa Inggris yang berbeda yaitu "Female Leadership in Banking and Bank Risk". Tes dilaksanakan secara tertulis, bentuk tes terdiri dari sepuluh pertanyaan dan mahasiswa harus menjawab pertanyaan tersebut berdasarkan bacaan berupa jurnal berbahasa Inggris yang telah diberikan. Dari postes yang telah dilaksanakan tersebut diperoleh nilai dari mahasiswa seperti yang terlihat pada tabel berikut ini.

Tabel 2.

Nilai Postes Mahasiswa

\begin{tabular}{|c|l|c|}
\hline $\begin{array}{c}\text { Nomor } \\
\text { Urut }\end{array}$ & Mahasiswa & $\begin{array}{c}\text { Nilai } \\
\text { postes }\end{array}$ \\
\hline 1. & Mahasiswa 1 & 6 \\
\hline 2. & Mahasiswa 2 & 8 \\
\hline 3. & Mahasiswa 3 & 7 \\
\hline 4. & Mahasiswa 4 & 8 \\
\hline 5. & Mahasiswa 5 & 6 \\
\hline 6. & Mahasiswa 6 & 8 \\
\hline 7. & Mahasiswa 7 & 6 \\
\hline 8. & Mahasiswa 8 & 6 \\
\hline 9. & Mahasiswa 9 & 8 \\
\hline
\end{tabular}


MEDIASI Vol. 1 No. 3, September 2020

Hanif Safika Rizky, Yenni Khristiana

\begin{tabular}{|c|l|l|}
\hline 10. & Mahasiswa 10 & 7 \\
\hline 11. & Mahasiswa 11 & 7 \\
\hline 12. & Mahasiswa 12 & 8 \\
\hline 13. & Mahasiswa 13 & 6 \\
\hline 14. & Mahasiswa 14 & 6 \\
\hline 15. & Mahasiswa 15 & 8 \\
\hline 16. & Mahasiswa 16 & 7 \\
\hline 17. & Mahasiswa 17 & 8 \\
\hline 18. & Mahasiswa 18 & 5 \\
\hline 19. & Mahasiswa 19 & 7 \\
\hline 20. & Mahasiswa 20 & 8 \\
\hline
\end{tabular}

Untuk mengetahui kemampuan mahasiswa yang telah diberikan pembelajaran tentang cara menggunakan skimming method dalam membaca jurnal berbahasa Inggris, apakah dapat meningkat atau tidak, maka diadakan pretes dan postes. Sebelum pembelajaran dilaksanakan, diadakan tahapan pretes kepada mahasiswa dan pada tahap akhir diadakan postes setelah adanya pembelajaran bagaimana penggunaan skimming method dalam membaca jurnal berbahasa Inggris. Di sini peneliti menggunakan teknik Uji T untuk mengetahui hasil tes mahasiswa dari sebelum dan sesudah diberikan pembelajaran skimming method dalam membacajurnal berbahasa Inggris. Hasilnya diperoeh perbandingan kemampuan Bahasa Inggris mahasiswa dari pretes dan postes sebagai berikut:

Tabel 3 .

Perolehan Hasil Tes Mahasiswa dengan Penggunaan Teknik Perhitungan Uji T

\begin{tabular}{|c|c|c|c|c|c|}
\hline No & Pretes & Postes & Gain $d$ & $\mathrm{Xd}(\mathrm{d}-\mathrm{Md})$ & $\mathrm{Xd}^{2}$ \\
\hline 1. & 5 & 6 & 1 & -0.65 & 0.4225 \\
\hline 2. & 5 & 8 & 3 & 1.35 & 1.8225 \\
\hline 3. & 6 & 7 & 1 & $-0,65$ & 0,4225 \\
\hline 4. & 7 & 8 & 1 & $-0,65$ & 0,4225 \\
\hline 5. & 6 & 6 & 0 & $-1,65$ & 2,7225 \\
\hline 6. & 7 & 8 & 1 & $-0,65$ & 0,4225 \\
\hline 7. & 4 & 6 & 2 & 0,35 & 0,1225 \\
\hline 8. & 5 & 6 & 1 & $-0,65$ & 0,4225 \\
\hline 9. & 6 & 8 & 2 & 0,35 & 0,1225 \\
\hline 10. & 6 & 7 & 1 & $-0,65$ & 0,4225 \\
\hline 11. & 7 & 7 & 0 & $-1,65$ & 2,7225 \\
\hline 12. & 7 & 8 & 1 & $-0,65$ & 0,4225 \\
\hline 13. & 5 & 6 & 1 & $-0,65$ & 0,4225 \\
\hline 14. & 5 & 6 & 1 & $-0,65$ & 0,4225 \\
\hline 15. & 5 & 8 & 3 & 1,35 & 1,8225 \\
\hline 16. & 6 & 7 & 1 & $-0,65$ & 0,4225 \\
\hline 17. & 7 & 8 & 1 & $-0,65$ & 0,4225 \\
\hline 18. & 4 & 5 & 1 & $-0,65$ & 0,4225 \\
\hline 19. & 5 & 7 & 2 & 0,35 & 0,1225 \\
\hline 20. & 6 & 8 & 2 & 0,35 & 0,1225 \\
\hline & & & $\Sigma \mathrm{d}=26$ & & 14,65 \\
\hline
\end{tabular}




$$
\begin{aligned}
& \mathrm{Md}=\frac{\frac{E d}{N}}{20}=1,3 \\
& \mathrm{t}=\frac{\frac{26}{20}}{\sqrt{\frac{\Sigma x^{2} d}{N(\mathrm{~N}-1)}}} \\
& \mathrm{t}=\frac{1,3}{\sqrt{\frac{14,65}{20 \times 18}}}=\frac{1,3}{\sqrt{0,039}} \\
& \mathrm{t}=\frac{1,3}{0,197}=6,6 \\
& \mathrm{t}_{0,05=1,72} \\
& \mathrm{t}=6,6>1,72
\end{aligned}
$$

Pada data tersebut terlihat jumlah t table adalah $t=0,05=1,72$. Dengan demikian didapatkan thitung yaitu lebih besar dari pada t tabel sehingga yang terjadi adalah hasil pretes dan postes menunjukkan signifikansi atau peningkatan. Maka hasil tersebut menunjukkan bahwa kemampuan Bahasa Inggris dan pemahaman terhadap isi jurnal berbahasa Inggris oleh mahasiswa meningkat. Hal ini dapat terjadi karena mahasiswa sanggup memahami dan dapat menggunakan atau mengaplikasikan skimming method dalam membaca jurnal berbahasa Inggris.

\section{SIMPULAN}

Merujuk dari hasil analisis data tersebut yakni dengan membandingkan nilai pretes dan postes mahasiswa STIE AUB Surakarta dengan teknik Uji t menunjukkan bahwa hasil 6,6 > 1,72 (signifikan). Maka dapat disimpulkan oleh peneliti bahwa penggunaan skimming method dalam membaca jurnal berbahasa Inggris oleh mahasiswa di STIE AUB Surakarta dapat meningkatkan penguasaan bahasa Inggris dan pemahaman terhadap isi jurnal berbahasa Inggris mereka. Adapun saran untuk peneliti berikutnya yaitu gunakanlah metode membaca yang lain pada proses belajar dan mengajar Bahasa Inggris misalnya menggunakan selecting method dengan objek yang lain.

\section{DAFTAR RUJUKAN}

Ahmad, L. (2010). Speed Reading. Jogjakarta: A Plus Books.

Fitria, N, T \& Heliawan, A,Y. (2017). Meningkatkan Kemampuan Mahasiswa Prodi S-1 Akuntansi dalam Memahami Buku, Ebook, dan Artikel/Jurnal Akuntansi Berbahasa Inggris. Jurnal Akuntansi dan Pajak, 02: 1-13.

Mulyadi. (2014). Kontribusi Penguasaan Kosakata dan Kemampuan Membaca Pemahaman terhadap Hasil Belajar Bahasa Indonesia Siswa Kelas XI SMA Swasta Bukittinggi Padang. Program Pasca SarjanaUniversitas Negeri Padang. 
Noverilan. (2012). Kontribusi Kemampuan Membaca Pemahaman dan Motivasi Belajar terhadap Keterampilan Menulis Argumentasi Siswa Kelas X SMA Negeri 4 Padang. Program Pasca Sarjana Universitas Negeri Padang.

Puspita, T,P. (2018). Pengaruh Kecepatan Membaca Terhadap Pemahaman Konten Bacaan. Universitas Airlangga.

Soenardi, D. (2011). Tes Bahasa Pegangan Bagi Pengajar Bahasa. Jakarta: PT Indeks.

Sudrajat, D. (2015). Studi Tentang Pelaksanaan Pengajaran Bahasa Inggris di SD Kota Tenggarong. Jurnal Pendidikan dan Pembelajaran, 01: 13-24.

Supriatnoko \& Redyanita, H. (2017). Peningkatan Kemahiran Berbicara Bahasa Inggris Mahasiswa Politeknik Negeri Jakarta Melalui Magic Five Fingers Method. Jurnal Epigram, 02: 161-172.

Suryoputro, G, Riadi, S, \& Sya'ban, A. (2012). Menulis Artikel Untuk Jurnal Ilmiah. Jakarta Selatan: Uhamka Press. 